\title{
David Oliver: Nurses, degrees, and the workforce crisis
}

\author{
David Oliver consultant in geriatrics and acute general medicine
}

Berkshire

The biggest threat to the NHS's existence is its workforce crisis. And, although modern healthcare is a team venture reliant on interdisciplinary working, nursing is the NHS's most numerous, visible, and trusted clinical workforce group. One with a workforce crisis even more pressing than that in medicine. ${ }^{1}$

Against this backdrop, the zombie trope I've mentioned before in this column ${ }^{2}$ - that "overeducated nurses" lead to declining standards of care-has made an unwelcome return in parts of the media. It seems a peculiarly British obsession, as graduate nursing is established in most developed nations-but it's hard to kill off.

In a 2014 study in nine European countries, every 10\% increase in degree educated nurses was associated with a $7 \%$ reduction in patient mortality. England had one of the lowest percentages of graduate nurses in its bedside workforce. ${ }^{3}$ Then we have the immense (and growing) contribution to patient care by advanced nurse practitioners educated to masters level, in services throughout the NHS. ${ }^{4}$

\section{Lines of argument}

Yet last month saw a series of posts by the journalist Harriet Sergeant, who has criticised nursing degrees on and off for years, claiming that "the rot set in" in nursing care with the introduction of bachelors degrees as standard-that this somehow worsened care (though with no evidence beyond anecdotes) and that it deterred potential applicants with the right skills. ${ }^{5}$ Letters appeared in the Times ${ }^{6}$ and the Telegraph ${ }^{7}$ from readers banging the same drum. The lines of argument are ill informed about modern healthcare and nursing roles, the complexity and acuity of patients, the range of technologies, the pressure on services, and the growth in evidence for practice. Different eras require different approaches.

In essence the correspondents argue that, by requiring degrees, we'll exclude people with the right skills from becoming nurses. What nurses mostly need, they say, are innate values of compassion, caring, and common sense, for what should be a vocation, not a profession: nursing degrees somehow render nurses incapable of compassion and empathy, uninterested in practical, hands-on care, despite graduate nurses throughout the NHS delivering precisely this.
We hear calls to "bring back" old-style training based on paid ward work with a classroom component, although modern nursing degrees, contrary to mythology, have a standard requirement for over 2000 hours training in clinical practice. ${ }^{8}$ Despite our understanding that improving quality and safety ${ }^{9}$ requires flat hierarchies, teamwork, an open and just culture, and an awareness of human and system factors - and despite a move away from regimented, institutionalised care-many still long for an era when "matrons were feared" and nursing could magically be reduced to nutrition, pressure sore prevention, spotless environments, and crisp uniforms.

We don't see these wholly unevidenced arguments or assumptions made about doctors or a range of allied health professionals: behind them lies an unhealthy dose of covert snobbery and sexism. And a move to nursing degrees needn't be some kind of insult to nurses in an era when degrees weren't required. Professional training moves on.

\section{Proposed solutions}

Several factors are driving the workforce crisis in nursing. These include removing nursing study bursaries ${ }^{10}$; deliberate decisions to cut funding, staffing, and CPD budgets for Health Education England $^{11}$; insufficient availability of student clinical placements and their funding ${ }^{12}$; immigration visa ${ }^{13}$ and English language test rules, ${ }^{14}$ which put off applicants trained overseas; and the workload terms and conditions, falling morale, and burnout that mean more nurses leaving the workforce or choosing less than full time working. ${ }^{1915}$ Some solutions are proposed in the Closing the Gap report ${ }^{1}$ and the preliminary NHS People Plan. ${ }^{16}$ And NHS England is investing in more flexible routes to degrees, including apprenticeships and new nursing associate roles, ${ }^{17}$ which partly address some of the "back to the future" calls.

Whatever's causing our problems in nursing, they won't be solved by giving people less education and training - an argument that should surely have had its day.

Competing interests: See www.bmj.com/about-bmj/freelance-contributors. Provenance and peer review: Commissioned; not externally peer reviewed. 
1 King's Fund. Closing the gap: key areas for action on the health and care workforce. 21 Mar 2019. https://www.kingsfund.org.uk/publications/closing-gap-health-care-workforce.

Oliver D. David Oliver: Why shouldn't nurses be graduates?BMJ 2017;356:j863. https:// www.bmj.com/content/356/bmj.j863. 10.1136/bmj.j863 28292770

3 Nurse staffing and education and hospital mortality in nine European countries: a retrospective observational study. Aiken LH, Sloane DM, Bruyneel L, et al. Lancet 2014;383:1824-30. https://www.thelancet.com/journals/lancet/article/PIIS0140-6736(13) 62631-8/fulltext.

4 Baileff A. The role of advanced nurse practitioners. Nursing in Practice 2015 May 19 https://www.nursinginpractice.com/article/role-advanced-nurse-practitioners.

5 Sergeant $\mathrm{H}$. Twitter post. 10 May 2019. https://twitter.com/harrietsergeant/status/ 1126798930874982401

6 Richardson B. Letter: Nurse shortage and training on the job. Times 2019 May 9.

7 Barnes G, Thorp A. Letters: Vocational nursing. Daily Telegraph 2019 May 23.

8 Nursing and Midwifery Council. Standards for pre-registration nursing education. $16 \mathrm{Sep}$ 2010. https://www.nmc.org.uk/globalassets/sitedocuments/standards/nmc-standards-forpre-registration-nursing-education.pdf.

9 Mannion R, Davies H. Understanding organisational culture for healthcare quality improvement. BMJ 2018;363:k4907. https://www.bmj.com/content/363/bmj.k4907. 10.1136/bmj.k4907 30487286

10 Royal College of Nursing. "Removing the student nurse bursary has been a disaster." 12 Jul 2018. https://www.rcn.org.uk/news-and-events/news/removing-the-student-nursebursary-has-been-a-disaster.
11 Rimmer A. HEE staff cuts threaten medical education and patient care, BMA and unions warn. BMJ 2017;356:j1069. https://www.bmi.com/content/356/bmj.j1069. $10.1136 / \mathrm{bmj} . j 106928246096$

12 Ford M. NHS to fund 5000 extra nurse placements to expand workforce. Nursing Times 2019 Jan 7. https://www.nursingtimes.net/news/education/nhs-to-fund-5000-extra-nurseplacements-to-expand-workforce/7027310.article.

13 Grierson J, Campbell D, Walker P. Immigration cap on doctors and nurses to be lifted to relieve NHS. Guardian 2018 Jun 14. https://www.theguardian.com/society/2018/jun/14/ sajid-javid-confirms-cap-on-foreign-doctors-and-nurses-will-be-lifted.

14 Kendall-Raynor P. English language test: new hope for more than 1000 foreign nurses. Nursing Standard 2019 Nov 28. https://rcni.com/nursing-standard/newsroom/news/englishlanguage-test-new-hope-more-1000-foreign-nurses-142346.

15 Charlesworth A. How can we ensure the NHS has the workforce it needs? Health Foundation. 31 Oct 2017. https://www.health.org.uk/newsletter-feature/how-can-weensure-the-nhs-has-the-workforce-it-needs? gclid=Cj0KCQjwi43oBRDBARIsAExSRQGLTv6GgnoCHuqFbjDIX4EbugtzG4aXRV3D5LZtVkGF-4d2MX0sYOaAnI5EALw_wcB.

16 Edwards N, Palmer B. A preliminary workforce plan for the NHS. BMJ 2019;365:14144 https://www.bmj.com/content/365/bmj.l4144. 10.1136/bmj.14144. 31186233

17 NHS England. NHS publishes latest NHS staff survey results. 26 Feb 2019. https://www. england.nhs.uk/2019/02/nhs-publishes-latest-nhs-staff-survey-results/.

Published by the BMJ Publishing Group Limited. For permission to use (where not already granted under a licence) please go to http://group.bmj.com/group/rights-licensing/ permissions 